\title{
Functional Substance P Receptors on a Rat Pancreatic Acinar Cell Line ${ }^{1}$
}

\author{
M. D. WOMACK, ${ }^{2}$ M. R. HANLEY, ${ }^{*}$ and T. M. JESSELL ${ }^{3}$ \\ Department of Neurobiology, Hanard Medical School, Boston, Massachusetts 02115 and * Department of Biochemistry, Imperial \\ Collge, London SW7 2AZ, United Kingdom
}

\begin{abstract}
A pancreatic acinar cell line, AR4-2J, that expresses a high density of substance $P$ (SP)-binding sites has been identified. SP-binding sites on intact AR4-2J cells were detected with ${ }^{125}$ I-Bolton-Hunter SP $\left({ }^{125}\right.$ |-BHSP). ${ }^{125}$ I-BHSP binding to AR42J cells has an apparent $K_{d}$ of $40 \mathrm{pm}$ with slow rates of association and dissociation. The number of high affinity binding sites was about $10^{4} /$ cell. Binding of ${ }^{125}$-BHSP was inhibited by SP and by structurally related peptides. Physalaemin was a more potent inhibitor of binding than SP, whereas kassinin, eledoisin, and neurokinin A (substance $K$, neuromedin $\alpha$, or neurokinin L) were much less potent. SP. free acid and SP (7-11) were 3 to 4 orders of magnitude less potent than SP itself.

The membrane, intracellular, and secretory events elicited by exposure of AR4-2J cells to SP have also been examined. Intracellular recording from AR4-2J cells revealed resting membrane potentials of $\mathbf{- 4 0}$ to $-65 \mathrm{mV}$. Pressure application of SP ( $100 \mathrm{pm}$ to $100 \mathrm{~nm}$ ) evoked depolarizations of 20 to 40 $\mathrm{mV}$ which were maintained for prolonged periods. The intracellular free calcium concentration in AR4-2J cells, measured with (2-((2-amino-5-methylphenoxy)-methyl)-6-methoxy-8aminoquinolone tetra-acetoxy methyl ester), was between 100 and $500 \mathrm{~nm}$. Addition of SP (100 pM to $10 \mathrm{~nm}$ ) or physalaemin (1 $\mathrm{nM}$ ) induced a transient rise in intracellular free calcium. AR4-2J cells synthesize amylase, and exposure of cells to SP resulted in a dose-dependent increase in amylase secretion. Incubation of AR4-2J cells with several other secretagogues known to be effective on primary acinar cells
\end{abstract}

Received March 20, 1985; Revised May 3, 1985;

Accepted May 3, 1985

${ }^{1}$ This work was supported by National Institutes of Health Grant NS 17369 , by the McKnight Foundation, and by a DuPont Faculty Award to T. M. J. We are also grateful to Pfizer Inc., for a research grant and for generous provision of radiolabeled substance $P$ analogues. M. R. H. was supported by a North Atlantic Treaty Organization twinning grant. M. D. W. is in receipt of National Institutes of Health Training Fellowship NS-07112. We thank Dr. J. Maggio for a supply of synthetic substance K, P. Albert for advice and the facilities for measuring $\left(\mathrm{Ca}^{2+}\right)_{1}, \mathrm{C}$. Jahr for advice on the electrophysiology, and $\mathrm{J}$. Dodd for comments on the manuscript.

${ }^{2}$ To whom correspondence should be addressed, at her present address: Howard Hughes Medical Institute, Center for Neurobiology and Behavior, Columbia University College of Physicians and Surgeons, 722 West 168th St, New York, NY 10032

${ }^{3}$ Present address: Howard Hughes Medical Institute, Center for Neurobiology and Behavior, Columbia University College of Physicians and Surgeons, New York, NY 10032. did not evoke amylase release; however, bombesin (1 $\mu \mathrm{m}$ ) caused a significant increase in amylase secretion.

AR4-2J cells, therefore, retain many of the differentiated properties of primary acinar cells and should be useful for examining the structure and function of SP receptors.

Substance P (SP) is the best characterized member of a family of structurally related mammalian tachykinin peptides that are found in both central and peripheral neurons (Porter and O'Connor, 1982; Jessell, 1983; Kanazawa et al., 1984; Minamino et al., 1984). Although two other mammalian tachykinins, ${ }^{4}$ neurokinin A (substance $\mathrm{K}$, ncurokinin $\alpha$, or ncuromedin $\mathrm{L}$ ) and neurokinin $\mathrm{B}$ (neuromedin $\mathrm{K}$ or neurokinin $\beta$ ) have recently been isolated (Kangawa et al., 1983; Kimura et al., 1983; Maggio et al., 1983), the physiological role of SP has been examined in greatest detail (Jessell, 1983). SP is released from sensory terminals in sympathetic ganglia (Konishi et al., 1980) and in the superficial dorsal horn of the spinal cord (Yaksh et al., 1980) and appears to mediate slow excitatory postsynaptic potentials at sensory synapses (Konishi et al., 1980; Urban and Randic, 1984). The widespread projections of SP-containing neurons (Cuello et al., 1982; Hokfelt et al., 1982) suggests that SP may play important roles in neurotransmission at other central and peripheral synapses.

Variation in the potency of SP, other vertebrate tachykinins and synthetic SP analogues in different bioassay systems (Lee et al., 1982) and in displacing binding of radiolabeled tachykinins (Buck et al., 1984; Cascieri et al., 1985) has provided indirect evidence for the presence of subclasses of mammalian tachykinin receptors. SP has been proposed to interact preferentially with SP-P receptors, whereas neurokinins A and B (Kimura et al., 1983; Maggio et al., 1983) may represent endogenous ligands for the SP-E receptor sites. Autoradiographic Iocalization of tachykinin-binding sites in the CNS has demonstrated that the distribution of SP- and neurokinin A-binding sites differs within discrete regions of the CNS (Mantyh et al., 1984b), providing further evidence for distinct receptor subtypes.

In many regions of the CNS, immunocytochemical and autoradiographic studies have revealed a mismatch in the distribution of specific tachykinin peptides and their binding sites (Quirion et al., 1983; Mantyh et al., 1984a, b). Furthermore, the excitatory actions of endogenous tachykinins on central neurons have been reported

\footnotetext{
${ }^{4}$ A committee which met in August, 1984 at the IUPHAR Satellite Symposium on Substance P-Metabolism and Biological Actions has recommended that the tachykinin known as substance $\mathrm{K}$, neurokinin $\alpha$ or neuromedin $L$ should be referred to as neurokinin $A$, and that the tachykinin known as neurokinin $\beta$ or neuromedin $K$ should be referred to as neurokinin $B$ (Harmar and Keen, 1984).
} 
to correlate more closely with the distribution of receptor subtypes than with the presence of the peptides (Innis et al., 1984). These observations emphasize that a physiological role for tachykinins released from central and peripheral neurons is likely to be dependent on the presence of appropriate classes of tachykinin receptors on target cells.

Tachykinin receptors have also been demonstrated on several exocrine secretory cells (Jensen and Gardner, 1979; Liang and Cascieri, 1981). The uniformity and accessibility of acinar cells have permitted a more detailed analysis of tachykinin specificity and of some of the biochemical consequences of receptor activation than has been possible on central neurons. Parotid acinar cells have been examined in greatest detail and appear to express only the SP-P class of tachykinin-binding site (Cascieri et al., 1985). The activation of tachykinin receptors on parotid acinar cells has been shown to enhance $\mathrm{Ca}^{2+}$ influx (Putney et al., 1978; Liang and Cascieri, 1979), depolarize acinar cells (Peterson, 1980), and induce the release of amylase (Liang and Cascieri, 1979; Brown and Hanley, 1981). Similar effects of SP have been detected on pancreatic acinar cells (Sjodin et al., 1980). SP and related mammalian tachykinin peptides are present in vagal sensory fibers that terminate in the vicinity of parotid and pancreatic acinar cells (Larsson, 1979; Sharkey and Williams, 1983). The release of tachykinins from sensory terminals may therefore play a physiological role in the regulation of acinar cell secretion (Gallacher, 1983).

A biochemical and molecular analysis of tachykinin receptors will be important in determining the structural basis for differences in the actions of mammalian tachykinins. The heterogeneity of cell types and the multiplicity of binding sites have, however, made it difficult to approach this problem using neuronal cells as a source of receptors. The identification of clonal cell lines that express tachykinin receptors and retain differentiated cellular properties might provide a more suitable preparation for structural analysis of tachykinin receptors and for examining the membrane, intracellular, and secretory events triggered by activation of defined receptor subtypes.

We describe here the identification of a rat pancreatic acinar cell line that expresses a high density of SP receptors. These cells respond to SP with changes in membrane potential, transient changes in intracellular calcium levels, and secretion of amylase. Preliminary accounts of this work have been reported (Hanley and Jessell, 1984; Womack et al., 1984).

\section{Materials and Methods}

Culture. AR4-2J cells (Jessop and Hay, 1980) were obtained from the American Type Culture Collection (passage 13) and grown in tissue culture flasks in L-15 $\mathrm{CO}_{2}$ medium supplemented with penicillin/streptomycin, 50 units/ml (Flow Laboratories), glutamine (2 mM), glucose (44 mm), essential vitamins (Flow Laboratories), and $20 \%$ fetal calf serum (Dutchland, batch 12103043 ) at $37^{\circ} \mathrm{C}$ in $95 \%$ air: $5 \% \mathrm{CO}_{2}$. Cells were fed every second day and passaged at $70 \%$ confluence with $0.1 \%$ trypsin (Flow Laboratories) in $\mathrm{Ca}^{2+} / \mathrm{Mg}^{2+}$-free medium. AR4-2J cells are extremely refractile and grow as small clusters on untreated tissue culture plastic (Fig. 1) with a doubling in cell number every 24 to $30 \mathrm{hr}$. In contrast, all other rodent and human pancreatic carcinoma cells we examined grow to confluence with flat epithelial morphology.

${ }^{125} /$-Bolton-Hunter substance $P$ binding. ${ }^{125}$-N-Succinimidyl-3-(4-hydroxyphenyl)proprionate-labeled SP ( ${ }^{125} \mathrm{I}-\mathrm{BHSP}$ ) (specific activity, $2200 \mathrm{Ci} / \mathrm{mmol}$ ) was prepared using a modification of the method of Bolton and Hunter (1973) and purified by high pressure liquid chromatography on a reverse phase $\mathrm{C}-18$ column in a solvent containing $27 \%$ acetonitrile, $0.1 \mathrm{~m}$ phosphate buffer, $\mathrm{pH} 3.5,50 \mathrm{~mm}$ 2-mercaptoethanol. ${ }^{125}$-BHSP was generously provided by M. Pagnozzi, E. Mena, and C. Pazoles, Pfizer Inc. AR4-2J cells were plated at a density of $10^{5}$ cells/well in 24 -well plates ( $16 \mathrm{~mm}$ diameter). Fortyeight to $72 \mathrm{hr}$ after plating, cells were washed twice with Hanks' balanced salts solution supplemented with $44 \mathrm{~mm}$ glucose and $0.4 \mathrm{mg} / \mathrm{ml}$ of bovine serum albumin (BSA) (fraction V; Sigma Chemical Co.) and incubated with ${ }^{125} \mathrm{I}-\mathrm{BHSP}$ in $0.5 \mathrm{ml}$ of Hanks' supplemented medium at $22^{\circ} \mathrm{C}$. Incubations were terminated by removal of medium and washing three times with Hanks' medium at $4^{\circ} \mathrm{C}$. AR4-2J cells were solubilized in $1 \%$ Triton X-100 containing

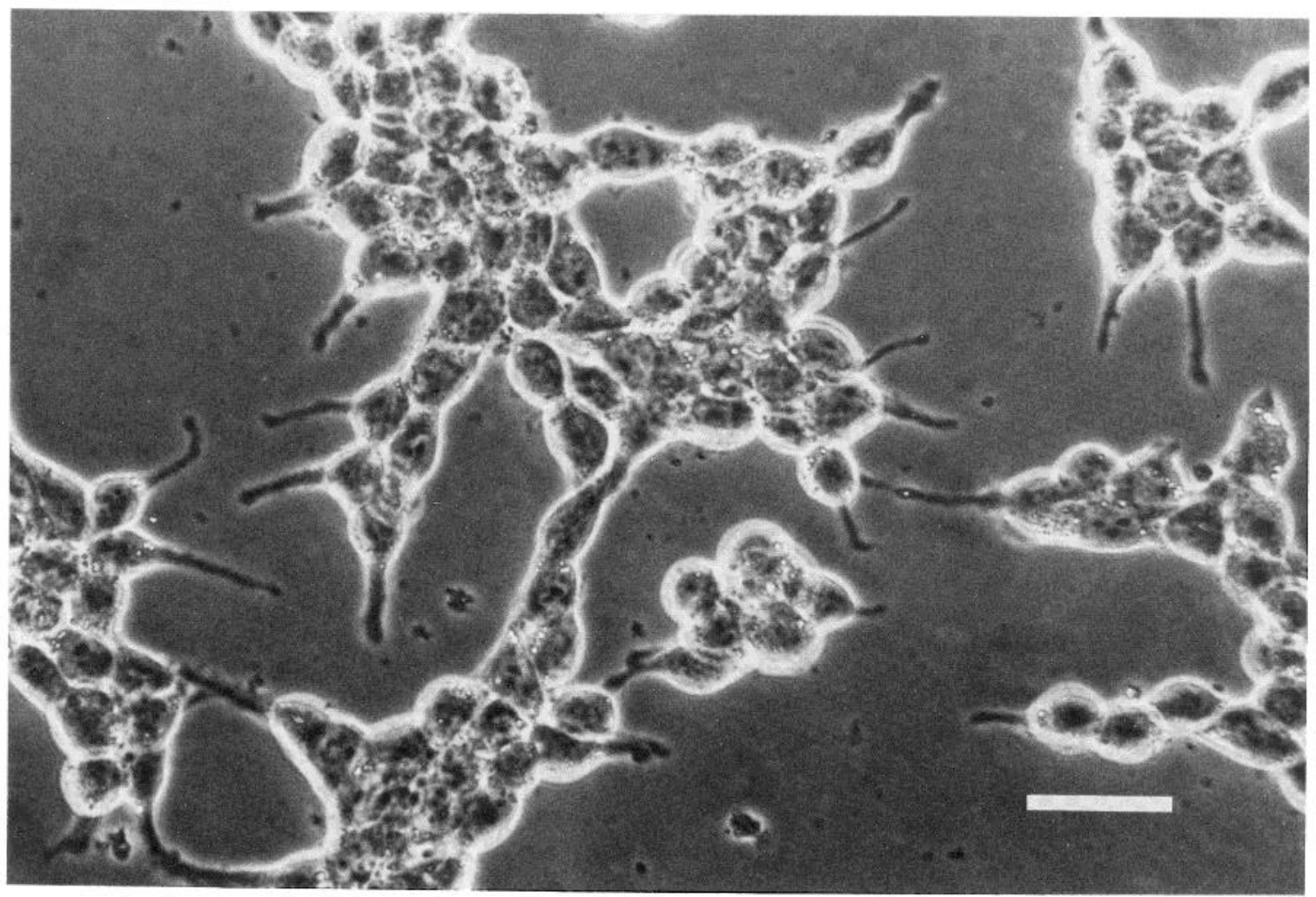

Figure 1. Phase contrast micrograph showing the appearance of AR4-2J cells after $48 \mathrm{hr}$ in culture. Cells grow in small clusters and are characterized by spindle-shaped projections. Scale bar $=40 \mu \mathrm{m}$. 
$1 \mathrm{mg} / \mathrm{ml}$ of BSA, and radioactivity was measured in a gamma counter. In control experiments, radiolabel bound to cells at the end of the incubation was analyzed by thin layer chromatography on Whatman LK60 plates and was shown to migrate as a single peak with the same $R_{f}$ value as authentic ${ }^{125}$-BHSP, indicating that there was no detectable breakdown of receptorbound ligand during incubation. Although we have not assessed the degradation of free ligand directly, addition of bacitracin $(10 \mathrm{mg} / \mathrm{ml})$, leupeptin (10 $\mu \mathrm{g} / \mathrm{ml})$, and chymostatin $(50 \mu \mathrm{g} / \mathrm{ml})$ to the incubation medium did not appear to enhance ${ }^{125}$ - $\mathrm{BHSP}$ binding to AR4-2J cells.

Since the ligand bound represented less than $5 \%$ of the total counts added to the incubation medium, the kinetics of binding were analyzed as a pseudo-first-order reaction, based on the assumption that there was no significant brcakdown of ligand during the incubation period (Kitabgi ct al., 1977). The association rate constant was calculated according to the equation, $k_{1}=\ln \left[\left(A_{\mathrm{eq}}\right) /\left(\left(A_{\mathrm{eq}}-\left(A_{\mathrm{t}}\right)\right)\right]\right.$, where $\left(A_{\mathrm{eq}}\right)$ represents the concentration of ligand bourid al equilibrium and $\left(A_{t}\right)$ represents the amount of ligand bound at each specified time. The rate constant of dissociation was calculated according to the equation: $k_{-1}=-\ln \left(\left(A_{t}\right) /\left(A_{0}\right)\right) / t$, where $\left(A_{0}\right)$ is the concentration of bound ligand at time $t=0$ and $\left(A_{t}\right)$ is the concentration bound at the time indicated.

Measurement of $\left(\mathrm{Ca}^{2+}\right)_{i}$. Change in intracellular calcium concentration $\left(\mathrm{Ca}^{2+}\right)_{i}$ were measured using (2-((2-amino-5-methylphenoxy)-methyl)-6-methoxy-8-aminoquinoline tetra-acetoxy methyl ester) (Quin 2-AM) essentially as described (Tsien et al., 1982; Albert and Tashilan, 1984). AR4-2J cells were scraped from culture flasks in $\mathrm{Ca}^{2+} / \mathrm{Mg}^{2+}$-free Eagle's minimal essential medium (S-MEM), centrifuged at $180 \times \mathrm{g}$ for $5 \mathrm{~min}$, and then resuspended in S-MEM supplemented with 5\% fetal calf serum. After incubation for 60 min at $37^{\circ} \mathrm{C}$, cells were washed twice with $20 \mathrm{ml}$ of Hanks' medium and then divided in aliquots of $10^{6}$ cells. Each aliquot was resuspended in $0.5 \mathrm{ml}$ of Hanks' medium and maintained at $37^{\circ} \mathrm{C}$ for 30 min to $2 \mathrm{hr}$ until used. AR4-2J cells were loaded by addition of $1 \mu \mathrm{l}$ of Quin 2-AM $(50 \mathrm{~mm}$ in dimethylsulfoxide (DMSO)) and incubated at $37^{\circ} \mathrm{C}$ for $30 \mathrm{~min}$. The Quin 2 AM was diluted by addition of $10 \mathrm{ml}$ of Hanks' medium, washed twice with $10 \mathrm{ml}$ of Hanks' medium, and resuspended in a final volume of $3 \mathrm{ml}$. Fluorescence was measured at $37^{\circ} \mathrm{C}$ with a Perkin-Elmer spectrofluorimeter (excitation, $340 \mathrm{~nm}$; emission, $492 \mathrm{~nm}$; 5-nm slit width). Cells were maintained in suspension by constant stirring during all measurements. After each experiment, the amount of Quin 2-AM incorporated in the cells was determined by measuring the fluorescence after solubilization with $25 \mu \mathrm{M}$ digitonin. Measurment of minimum fluorescence was obtained by addition of $1 \mathrm{~mm}$ excess EGTA to cell suspensions following addition of Tris buffer to increase the $\mathrm{pH}$ to 8.3. Transformation of the fluorescent signal to the logit scale of $\left(\mathrm{Ca}^{2+}\right)$ was performed using the equation $\left.\left(\mathrm{Ca}^{2+}\right)=K_{\mathrm{D}}\left(F-\mathrm{F}_{\min }\right) / F_{\max }-F\right)$ where $F$ is the fluorescence, on an arbitrary scale, $\Gamma_{\min }$ and $\Gamma_{\max }$ are the fluorescences at very low (in excess EGTA) and very high (in $1 \mathrm{mM} \mathrm{Ca}^{2+}$ ) levels, respectively, and $K_{\mathrm{D}}(=115 \mathrm{nM})$ is the effective dissociation constant of $\mathrm{Ca}^{2+}$-dye binding (Tsien et al., 1982). All drugs were added from 200 -fold concentrated stock solutions.

Electrophysiology. For electrophysiological experiments, AR4-2J cells were plated at a density of about $10^{4}$ cells $/ 35-\mathrm{mm}$ culture dish at least $48 \mathrm{hr}$ before recording. Intracellular recording from AR4-2J cells was performed on the stage of a Zeiss IM-30 inverted microscope under phase contrast optics. Recording medium contained $120 \mathrm{nM} \mathrm{NaCl}, 5.4 \mathrm{~mm} \mathrm{KCl}, 1.0 \mathrm{~mm} \mathrm{MgSO}_{4}, 1.2$ $\mathrm{mM} \mathrm{NaH}_{2} \mathrm{PO}_{4}, 3.6 \mathrm{~mm} \mathrm{CaCl}, 44 \mathrm{~mm}$ glucose, $\mathrm{pH}$ 7.2. Microelectrodes were filled with $2 \mathrm{M}$ potassium methylsulfate and had tip resistances between 150 and 250 megohms. SP and other drugs were applied in recording medium by pressure ( 3 p.s.i.) from a micropipette (tip diameter, 4 to $6 \mu \mathrm{m}$ ) positioned 20 to $50 \mu \mathrm{m}$ from the cell.

Measurement of amylase release. AR4-2J cells were grown at a density of $10^{5}$ cells/well in 16-mm-diameter multiwell plates for 48 to $72 \mathrm{hr}$ before measurement of amylase release. Since we frequently detected a large release of amylase after switching from L-15 growth medium to Hanks incubation medium, cells were preincubated for $30 \mathrm{~min}$ at $22^{\circ} \mathrm{C}$ in Hanks' medium containing $4 \mathrm{mg} / \mathrm{ml}$ of glucose, $0.4 \mathrm{mg} / \mathrm{ml}$ of BSA, $5 \mathrm{~mm}$ theophylline, $10 \mathrm{~mm}$ HEPES, $10 \mu \mathrm{g} / \mathrm{m}$ lo chymostatin, $10 \mu \mathrm{g} / \mathrm{ml}$ of leupeptin, $\mathrm{pH} 7.2$. After preincubation, AR4-2 J cells were incubated in $0.5 \mathrm{ml}$ of supplemented Hanks medium alone or in the presence of SP and other drugs. After $30 \mathrm{~min}$ at $22^{\circ} \mathrm{C}, 250 \mu \mathrm{l}$ of the medium were removed for analysis and the cells were lysed in $1 \%$ Triton $X-100 / 0.1 \%$ RSA at $4^{\circ} \mathrm{C}$, and $20-\mu$ l of cell extracts were taken for measurement of cellular amylase. $\alpha$-Amylase was assayed using a modification of the method of Fischer and Stein (1961). Medium aliquots and coll extracts were incubated with $1 \mathrm{ml}$ of starch solution $(5 \mathrm{mg} / \mathrm{ml})$ in phosphate buffer $(\mathrm{pH} 7.0)$ for $5 \mathrm{~min}$ at $25^{\circ} \mathrm{C}$. The reaction was stopped by adding $1 \mathrm{ml}$ of alkaline dinitrosalicylic acid solution, and the mixture was trealed in a boiling waler balt for 10 rnir. The solution was diluted wilt waler and the absorbance (1-cm light path) at $550 \mathrm{~nm}$ was measured. All samples were measured in duplicate and the amount of amylase was expressed as maltose equivalents. One unit of amylase was defined as the amount of the enzyme that caused the formation of $1 \mathrm{mg}$ maltose in $5 \mathrm{~min}$ at $25^{\circ} \mathrm{C}$.

Materials. Substance P, physalaemin, eledoisin, kassinin, and SP analogues and other peptides were obtained from Peninsula Laboratories or from Bachem, Inc. Synthetic substance $K$ was a gift from Dr. J. Maggio and subsequently was purchased from Peninsula Laboratories. Quin 2-AM was obtained from Polysciences. All other reagents were of analytical grade.

\section{Results}

Time course of association and dissociation of ${ }^{125} /$-BHSP binding to AR4-2J cells. ${ }^{125} \mathrm{I}-\mathrm{BHSP}$ bound specifically and reversibly to AR4$2 \mathrm{~J}$ cells grown in culture for 48 to $72 \mathrm{hr}$ after passaging. ${ }^{125} \mathrm{I}-\mathrm{BHSP}$ binding sites can be detected as early as $12 \mathrm{hr}$ after passaging and continue to be expressed for at least 14 days. The number of binding sites per culture well, determined $48 \mathrm{hr}$ after passaging, increases in proportion to cell number at densities from 10 to $70 \%$ confluency (data not shown). At $22^{\circ} \mathrm{C}$ and at a ${ }^{125} \mathrm{I}-\mathrm{BHSP}$ concentration of $80 \mathrm{pM}$, binding increased with time and reached a plateau after $60 \mathrm{~min}$ (Fig. 2A). Nonspecific binding, defined as the amount of ${ }^{125} \mathrm{I}-\mathrm{BHSP}$ bound in the presence of $10 \mu \mathrm{M}$ unlabeled SP, remained constant with increasing incubation times and represented less than $5 \%$ of total binding at equilibrium (Fig. 2A). ${ }^{125} \mathrm{~F}$-BHSP bound to AR4$2 \mathrm{~J}$ cells at equilibrium constituted about $5 \%$ of the total counts added to the incubation medium. The association rate constant of binding under these conditions was calculated according to the assumptions outlined by Kitabgi et al. (1977) and was determined to be $3.7 \times 10^{6} \mathrm{M}^{-1} \mathrm{sec}^{-1}$ (Fig. $2 B$ ). The rate of association was markedly dependent on temperature, as has been observed with froshly isolated pancreatic cells (Jensen and Gardner, 1979). At $4^{\circ} \mathrm{C}$, binding of ${ }^{125} \mathrm{I}-\mathrm{BHSP}$ to AR4-2J cells did not reach a plateau, even after several hours of incubation. At $37^{\circ} \mathrm{C}$, the amount of ${ }^{125} \mathrm{I}-\mathrm{BHSP}$ bound reached a peak after incubation for $30 \mathrm{~min}$ and then declined (not shown). This decrease in binding was not prevented by addition of several peptidase and protease inhibitors. A decrease in the binding of ${ }^{125}$-physalaemin to primary pancreatic acinar cells at $37^{\circ} \mathrm{C}$ has also been reported (Jensen and Gardner, 1979) and may result from proteolytic degradation of tachykinin ligands.

The rate constant of dissociation of ${ }^{125} \mathrm{I}-\mathrm{BHSP}$ from AR4-2J cells at $22^{\circ} \mathrm{C}$ was determined after ${ }^{125} \mathrm{I}-\mathrm{BHSP}$ binding reached equilibrium (90 min) (Fig. 3, $A$ and $B$ ). From the slope obtained from the dissociation data (Fig. $3 B$ ), a rate constant of dissociation of $1.56 \times$ $10^{-4} \mathrm{sec}^{-1}$ was calculated. From the values of the rate constants, the dissociation constant was calculated $\left(K_{\mathrm{D}}=k_{-1} / k_{1}\right)$ to be approximately $40 \mathrm{pm}$. From equilibrium binding data, the number of high affinity ${ }^{125} /$-BHSP-binding sites was calculated to be about 1.1 $\times 10^{4}$ /AR4-2J cell. Scatchard analysis (data not shown) of ${ }^{125}$-BHSP binding to AR4-2J cells resulted in a nonlinear plot similar to that reported for the binding of ${ }^{125} \mathrm{I}-\mathrm{BHSP}$ to brain and spinal cord membranes (Charlton and Helke, 1984; Cascieri et al., 1985) and to intact lymphoblasts (Payan et al., 1984) and suggests that the SPbinding sites on AR4-2J cells may exist in more than one affinity state. The affinity of ${ }^{125} \mathrm{I}$-BHSP binding also appears to be dependent on the integrity of the cells since we have found a lower affinity of binding to membrane fractions of AR4-2J cells (Hanley et al., 1984). A more detailed analysis of the kinetics of ${ }^{125}$-BHSP binding is in progress.

Competitive inhibition of ${ }^{125} /$-BHSP binding. In order to compare the ligand specificity of the SP receptors on AR4-2J cells with those expressed on acinar cells and neurons, the ability of SP and of several tachykinins and synthetic analogues to inhibit the binding of 125 $\mathrm{H}$-BHSP to AR4-2J cells was examined. SP inhibited ${ }^{125} \mathrm{I}-\mathrm{BHSP}$ binding in a competitive manner with an $\mathrm{IC}_{50}$ of $6 \times 10^{-10} \mathrm{M}$ (mean of 6 experiments) (Fig. 4). The relative potency of other tachykinins in inhibiting ${ }^{125}$-BHSP binding was in close agreement with the potency of the same compounds in inhibition of SP binding to membranes of acinar cells from guinea pig pancreas and to cells dissociated from rat parotid gland (Jensen and Gardner, 1979; Liang and Cascieri, 1981). Physalaemin was slightly more potent than SP 

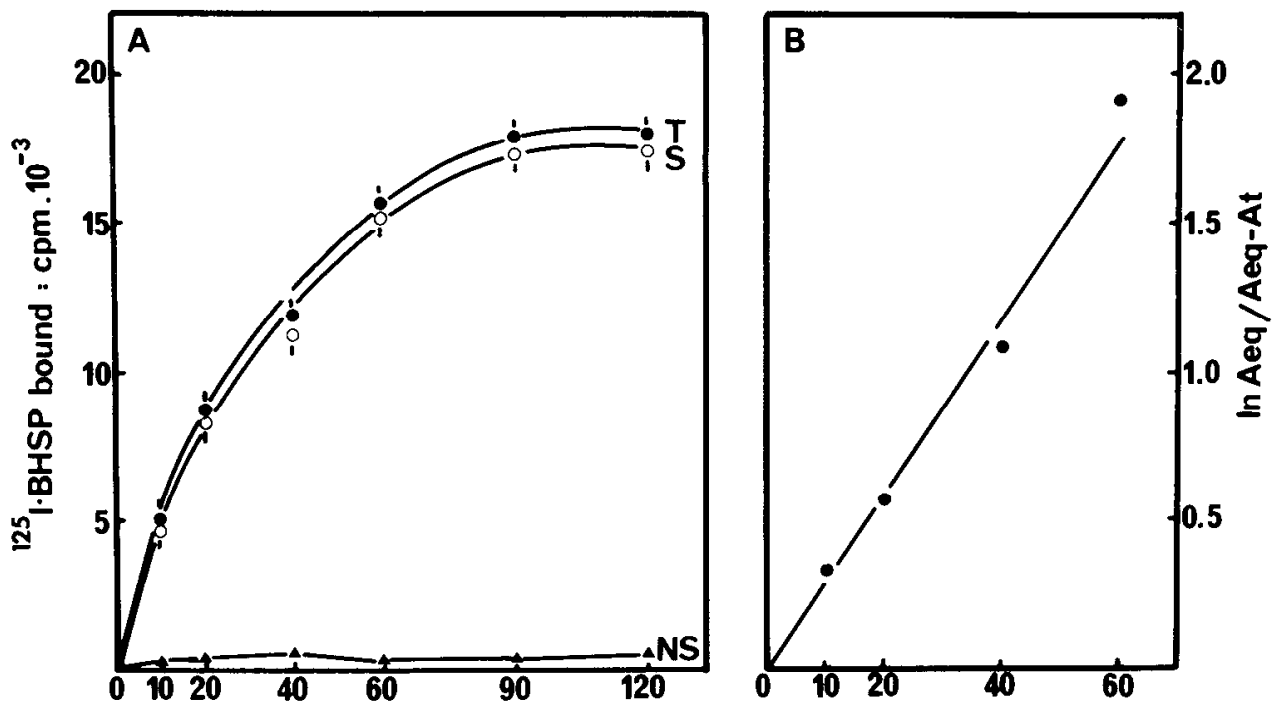

Figure 2. Time course of association of 125-BHSP to AR4-2J cells. AR4-2J cells were grown for 48 to $72 \mathrm{hr}$ in culture and incubated with ${ }^{125} \mathrm{I}$-BHSP $(80 \mathrm{pM})$ for different time periods. In $A$, the nonspecific (NS), total $(T)$, and specific $(S)$ binding per 16$\mathrm{mm}$ well is plotted as a function of time. In $B$ the data have been replotted as $\ln \left[\left(A_{\text {eq }}\right) /\right.$ $\left.\left(\left(A_{\text {eq }}\right)-\left(A_{t}\right)\right)\right]$ versus time. The rate of association, $k_{1}$, was calculated from the slope of $B$ as described under "Materials and Methods."

time, $\min \left(22^{\circ} \mathrm{C}\right)$
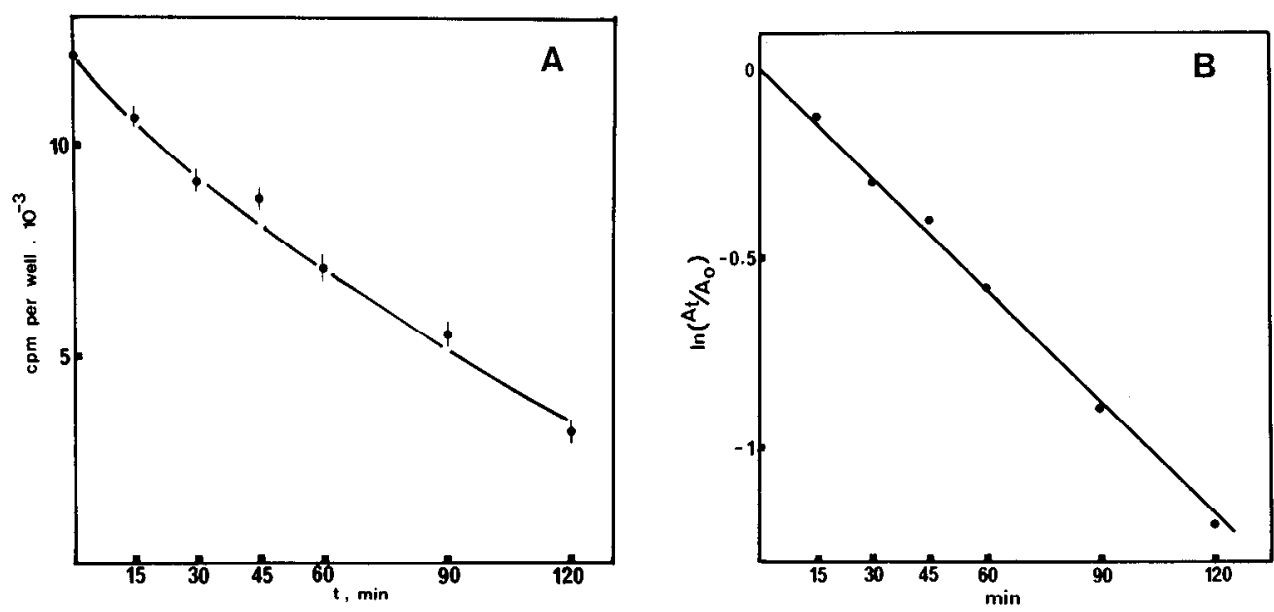

Figure 3. Time course of dissociation of ${ }^{125} \mathrm{I}$-BHSP bound to AR4-2J cells. ${ }^{125}$-BHSP (80 pM) was incubated for $90 \mathrm{~min}$ at $22^{\circ} \mathrm{C}$ with AR4-2J cells. The incubation medium was then removed and the cells were washed three times with medium at $22^{\circ} \mathrm{C}$ and replaced with $0.5 \mathrm{ml}$ of medium which was removed and replaced with fresh medium at the times indicated. In $A$ the counts per minute remaining associated with AR4$2 \mathrm{~J}$ cells is plotted as a function of time. Each point represents the mean \pm SEM of four determinations, with similar results obtained in three additional expcriments. In $B$, the results in $A$ are replotted as $\ln \left[\left(A_{t}\right) /\left(A_{0}\right)\right]$ against time. This plot is derived from the means of three separate experiments, per formed in quadruplicate. The rate of dissociation of ${ }^{25}$-BHSP was calculated as described under "Materials and Methods."

$\left(I C_{50}=3 \times 10^{-10} M\right)$, whereas eledoisin, kassinin, and neurokinin $A$ were one to two orders of magnitude less potent (Fig. 4).

Synthetic SP fragments varicd grcatly in thcir potency in inhibiting ${ }^{125} \mathrm{I}-\mathrm{BHSP}$ binding to AR4-2J cells. SP-free acid and the pentapeptide fragment SP $(7-11)$ were more than three orders of magnitude less potent than SP, whereas the hexapeptide SP (6-11) and longer fragments exhibited a progressive increase in potency compared to the pentapeptide (Fig. 5). The synthetic SP antagonist D-Arg ${ }^{1}-\mathrm{D}-\mathrm{Pro}^{2}$ D-Tryp ${ }^{7.9}$-Leu ${ }^{11}$ SP (Rosell et al., 1983) was about 100-fold less potent than substance $P$ in displacing ${ }^{125} \mathrm{I}-\mathrm{BHSP}$ (Fig. 5).

Several secretagogues and other compounds known to interact with receptors on primary pancreatic acinar cells (Petersen, 1980) were examined for their ability to inhibit the binding of ${ }^{125} \mathrm{~J}-\mathrm{BHSP}$ to AR4-2J cells. Bombesin, somatostatin, vasoactive intestinal polypeptide, neuropeptide $Y, D$-Ala-methionine enkephalin amide, norepinephrine, and bethanecol produced no inhibition of ${ }^{125}$-BHSP binding when included in the incubation medium at $10^{-7} \mathrm{M}$ (data not shown).

Transient changes in $\left(\mathrm{Ca}^{2+}\right)$ induced by SP in AR4-2J cells. We have examined whether SP-binding sites on AR4-2J cells are linked, functionally, to the same membrane, intracellular, and secretory events that have been reported to occur in primary acinar cells. Calcium is thought to play a role as second messenger in stimulus secretion coupling of pancreatic acinar cells (Petersen and Maruyama, 1984). SP has been reported to stimulate calcium influx in dispersed parotid acinar cells (Putney et al., 1978), suggesting that changes in intracellular calcium may mediate the secretory events elicited by SP. Direct measurement of $\left(\mathrm{Ca}^{2+}\right)_{\mathrm{i}}$ changes in pancreatic

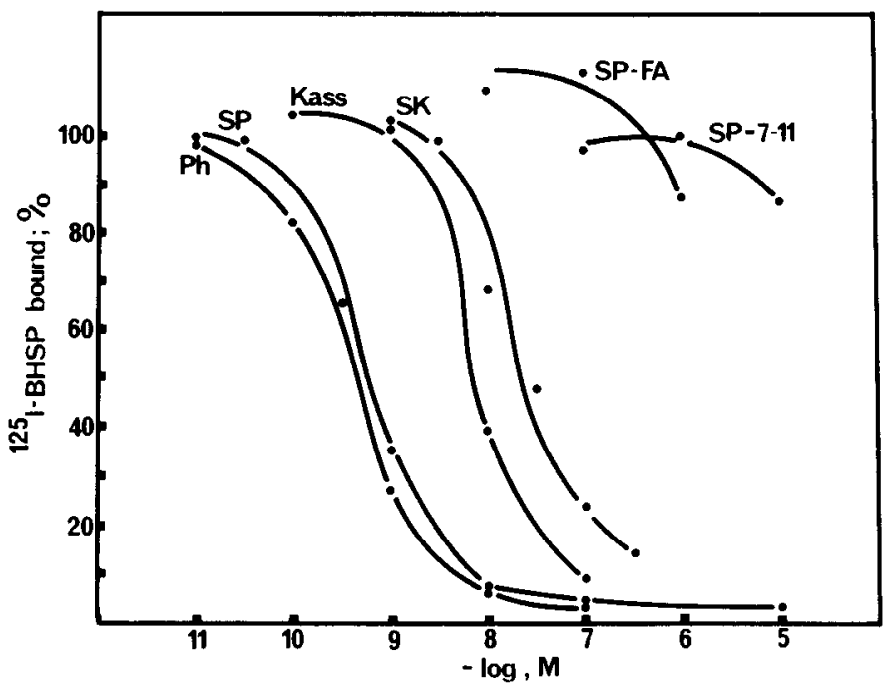

Figure 4. Competitive inhibition of ${ }^{125}$-BHSP binding to AR4-2J cells by SP and other mammalian and amphibian tachykinins. Increasing concentrations of unlabeled tachykinins were examined for their ability to displace ${ }^{125}$-BHSP binding to AR4-2J cells. Results are expressed as the percentage of binding of ${ }^{125} \mathrm{I} \mathrm{BHSP}$ in the absence of unlabeled tachykinin. Each point represents the mean \pm SEM of four determinations. Similar results were obtained in two additional experiments. Ph, physalaemin; Kass, kassinin; SK, neurokinin A; SP-FA, substance P-free acid; SP-7-11, C terminal pentapeptide fragment. 


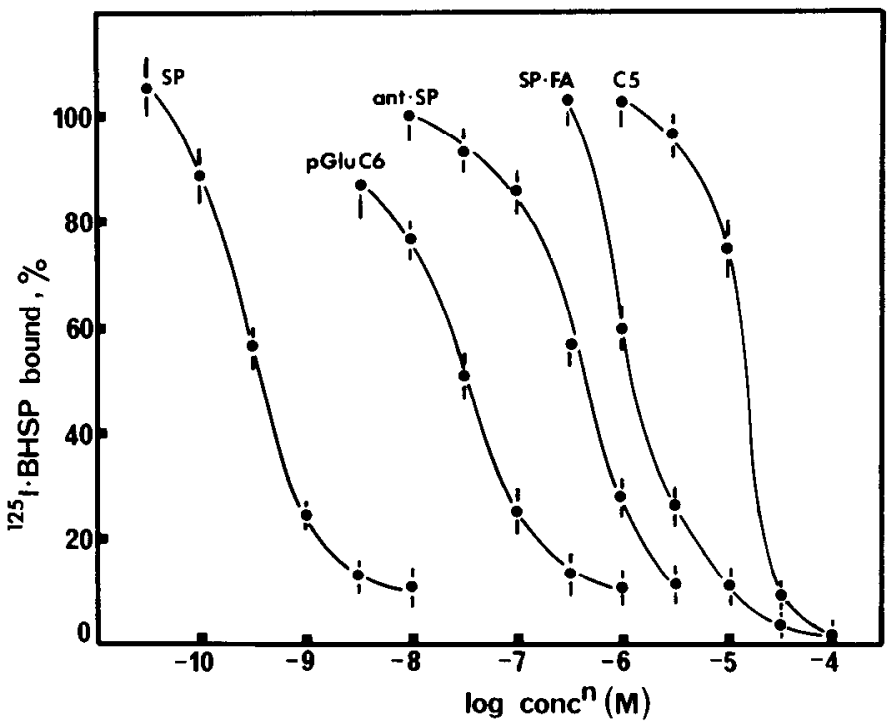

Figurc 5. Compctitive inhibiton of ${ }^{\mathrm{r}} \mathrm{H}-\mathrm{BHSP}$ binding to AR4-2J cells by SP and synthetic fragments and analogues of SP. Experiments were performed as described in the legend to Figure 4. $p G / u C 6$, pyroglutamyl substance $P$ 6-11; ant $\cdot S P$, D-Arg ${ }^{1}$-o-Pro ${ }^{2}$-D-Tryp ${ }^{79}$-Leu $^{11}$-substance $P$; SP.FA, substance P-free acid; C5, substance $P$ 7-11. acinar cells in response to other secretagogues have been reported using the calcium-selective fluorescence indicator Quin 2-AM (Ochs et al., 1983). We therefore examined whether occupation of SP. binding sites on AR4-2J cells resulted in changes in $\left(\mathrm{Ca}^{2+}\right)_{\mathrm{i}}$, that could be detected with Quin 2-AM.

AR4-2J cells loaded with Quin 2-AM exhibited low and constant fluorescence signals (Fig. 6A). The $\left(\mathrm{Ca}^{2+}\right)_{\text {; }}$ of unstimulated AR4-2J cells was calculated from the fluorescence of Quin 2-AM as described previously (Tsien et al., 1982), assuming a dissociation constant of $115 \mathrm{nM}$, and was in the range of 100 to $500 \mathrm{nM}(n=$ 12). These values are in agreement with the $\left(\mathrm{Ca}^{2+}\right)_{i}$ values reported for primary pancreatic acinar cells using Quin 2-AM (Ochs et al., 1983) or calcium-sensitive microelectrodes (O'Doherty and Stark, 1982). Addition of SP to the suspension of Quin 2-AM-loaded AR4$2 \mathrm{~J}$ cells caused a rapid increase in fluorescence (Fig. 6A) at a threshold concentration of $10^{-10} \mathrm{M}$. Higher concentrations of SP appeared to produce greater rises in $\left(\mathrm{Ca}^{2+}\right)_{\text {, }}$, although saturation of the fluorescence signal made a complete dose-response curve difficult to obtain. The maximal $\left(\mathrm{Ca}^{2+}\right)_{i}$ was measured within a few seconds of application of SP and decayed over a period of 30 to $60 \mathrm{sec}$ (Fig. 6A).

The pharmacological specificity of the SP-binding site mediating the increase in $\left(\mathrm{Ca}^{2+}\right)_{\mathrm{i}}$ appears similar to that detected in ligandbinding assays. Physalaemin $\left(10^{-9} \mathrm{M}\right)$ produced a rapid increase in $\left(\mathrm{Ca}^{2+}\right)_{i}$ that resembled the response to SP (Fig. $\left.6 B\right)$. In contrast, SP. free acid $\left(10^{-7} \mathrm{M}\right)$ produced no change in $\left(\mathrm{Ca}^{2+}\right)_{i}(\mathrm{Fig} .6 B)$. Carbachol

A
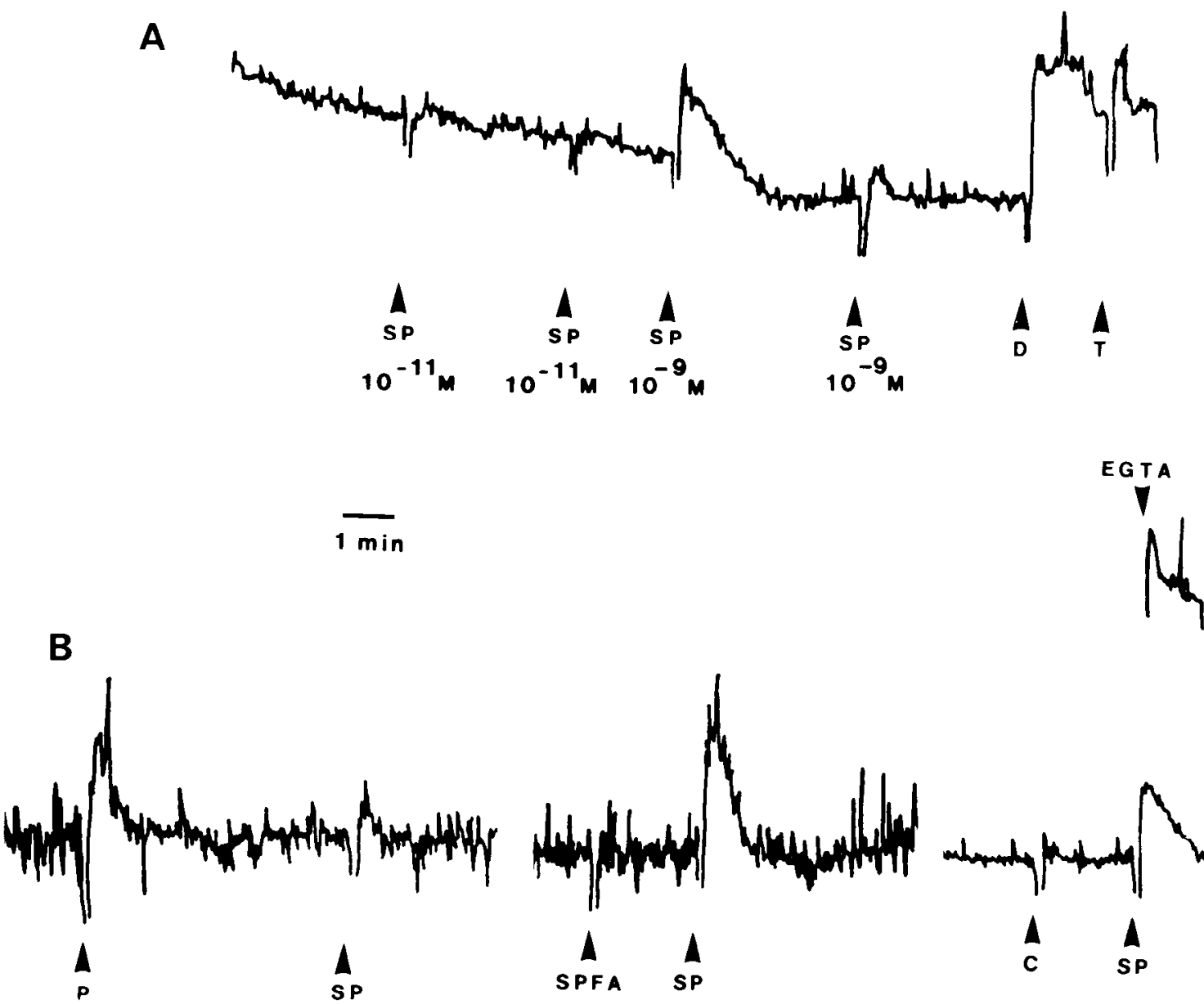

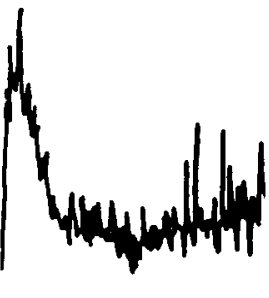

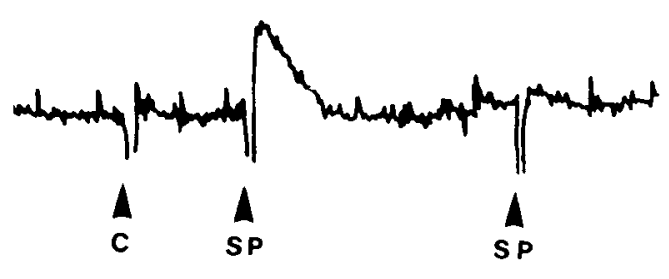

Figure 6. Measurement of intracellular calcium transients in AR4-2J cells using the fluorescent indicator Quin 2-AM. In A, application of SP (10 ${ }^{-11} \mathrm{M}$ ) failed to increase intracellular free calcium. Increasing the concentration of SP to $10^{-9} \mathrm{M}$ produced a transient increase in intracellular free calcium. Calibration of fluorescence signals was performed by permeabilizing cells with $50 \mu \mathrm{M}$ digitonin $(D)$ to obtain the maximum fluorescence signal. The minimum fluorescence signal was obtained after addition of excess $1 \mathrm{mM}$ EGTA to cell suspensions adjusted to $\mathrm{pH} 8.3$ with Tris $(T)$ buffer. $B$ shows the increase in intracellular frce calcium clicited by $10^{-9} \mathrm{M}$ (physalaemin $(P)$, but not by $10^{-9} \mathrm{M}$ substance P-free acid (SPFA) or $10^{-9} \mathrm{M}$ carbachol $(C)$. After applications of high concentrations of SP or physalaemin, subsequent application of SP $\left(10^{-9} \mathrm{M}\right)$ produced only small increases in fluorescence signal. 
has been reported to increase $\left(\mathrm{Ca}^{2+}\right)_{i}$ in acutely dissociated acinar cells (Ochs et al., 1983). However, addition of carbachol $\left(10^{-7} \mathrm{M}\right)$ to AR4-2J cells did not elicit any increase in $\left(\mathrm{Ca}^{2+}\right)_{i}$ (Fig. 6B), suggesting that muscarinic receptors are either absent or are not coupled to intracellular calcium mobilization in these cells. These observations suggest that SP-binding sites on AR4-2J cells are functional and that one consequence of activation of these sites by SP and related tachykinins is a rapid and transient increase in intracellular calcium.

Electrophysiological response of AR4-2J cells to SP. Several secretagogues that mobilize intracellular calcium in pancreatic acinar cells produce a depolarization of the acinar cell membrane that is accompanied by a conductance increase (Petersen and Maruyama, 1984). The effect of SP on the membrane electrical properties of pancreatic acinar cells has not been examined. However, application of SP to parotid acinar cells produces a marked depolarization and an increase in membrane conductance (Petersen, 1980). We used intracellular recording techniques to examine whether SP produced changes in the membrane potential of AR4-2J cells. Intracellular recordings were obtained and AR4-2J cells with resting membrane potentials of -40 to $-65 \mathrm{mV}$ were used for analysis.

In 10 AR4-2J cells from which stable recordings were obtained, pressure application of $\mathrm{SP}\left(10^{-9}\right.$ to $\left.10^{-7} \mathrm{M}\right)$ produced a pronounced membrane depolarization that ranged from 20 to $40 \mathrm{mV}$ (Fig. 7). There was no clear correlation between the amplitude of the SPinduced depolarization and the resting membrane potential, suggesting that variations in the amplitude of the depolarization may be due to differences in sensitivity of individual cells. However, the use of high resistance electrodes, necessary to obtain stable recordings, precluded accurate measurement of input resistance, and the effects of damage to the cells on SP responses could not be assessed. Some cells showed a decreased response with repeated application of SP at concentrations as low as $10^{-9} \mathrm{M}$ suggesting that desensitization to SP may occur (not shown).

There was a significant delay from the time of SP application to the onset of depolarization of AR4-2J cells (Fig. 7) that is unlikely to be caused by a delay in the time of diffusion of peptide from the pressure pipette to the cell membrane, since pressure pipettes were positioned within $50 \mu \mathrm{m}$ of the cell under study. It is possible, therefore, that the depolarization induced by SP results from the activation of a second messenger system, perhaps mediated by changes in intracellular calcium. The depolarization of SP-responsive AR4-2J cells was associated with an increase in membrane conductance (Fig. 7). It is unlikely that the increase in membrane conductance is due solely to the activation of voltage-dependent ion channels. Primary pancreatic acinar cells maintain a linear currentvoltage relationship over membrane potentials ranging from -20 to $-70 \mathrm{mV}$ (Nishiyama and Petersen, 1975), and depolarization evoked by $\mathrm{K}^{+}$is not associated with changes in the input resistance of these cells (Nishiyama and Petersen, 1974). Further studies will be necessary to determine the ionic basis of the SP-induced depolarization of AR4-2J cells.

$S P$ induced amylase release from AR4-2J cells. To determine whether increases in $\left(\mathrm{Ca}^{2+}\right)$, observed after SP application were associated with a secretory response in AR4-2J cells, we measured the effect of SP on amylase release. AR4-2J cells incubated in Hanks' medium appeared to release, constitutively, low levels of amylase. Addition of SP $\left(10^{-11}\right.$ to $\left.10^{-8} \mathrm{M}\right)$ to the incubation medium produced a dose-dependent increase in amylase release (Fig. $8 A$ ). The maximal amount of amylase released in response to SP was consistent between experiments. However, the basal amylase efflux from comparable numbers of cells exhibited up to 3 -fold variation, resulting in a 3- to 8-fold stimulation of amylase release in response to a near-maximal $\left(10^{-8} \mathrm{M}\right) \mathrm{SP}$ concentration. A half-maximal increase in amylase secretion was observed at an SP concentration of $3 \times$ $10^{-11} \mathrm{M}$. The secretagogic action of SP could also be detected by measuring the depletion in cellular stores of amylase (data not shown).

The release of amylase from AR4-2J cells in response to other known pancreatic secretagogues was determined in order to assess the presence of other functional membrane receptors. Incubation of AR4-2J cells with carbachol $\left(10^{-4} \mathrm{M}\right)$, bradykinin $\left(10^{-5} \mathrm{M}\right)$, secretin $\left(3 \times 10^{-6} \mathrm{M}\right)$, or norepinephrine $\left(10^{-3} \mathrm{M}\right)$ did not produce a significant release of amylase. Incubation with bombesin $\left(10^{-5} \mathrm{M}\right)$, however, evoked a 3 -fold increase in amylase release (Fig. $8 B$ ). No significant inhibition of ${ }^{125} \mathrm{I}-\mathrm{BHSP}$ binding was observed at this concentration of bombesin (not shown). Amylase release from AR4-2J cells has previously been reported to be unaffected by cholecystokinin (Jessop and Hay, 1980), however, the addition of glucocorticoids appears to confer cholecystokinin sensitivity (Logsdon et al., 1985).

\section{Discussion}

The AR4-2J cell line was derived from an azaserine-induced rat pancreatic tumor (Longnecker et al., 1979) and has been shown to possess several differentiated properties of pancreatic acinar cells. AR4-2J cells have been shown to contain amylase and other exocrine enzymes (Jessop and Hay, 1980) and have served as a model system with which to examine the regulation of chymotrypsin gene expression (Walker et al., 1983). The studies described here demonstrate that AR4-2J cells also express functional tachykinin receptors which exhibit structural requirements for ligand binding similar to those exhibited by tachykinin receptors on primary acinar cells.

At present this is the only pancreatic cell line on which we have detected tachykinin receptors. No significant binding of ${ }^{125}$-BHSP was observed to the rat pancreatic lines AR4-1P (Jessop and Hay, 1980 ), $\wedge T_{3} A$, or $A T_{3} B$ (Rao ct al., 1980) or to the human pancreatic adenocarcinoma line Capan-2 (Fogh, 1975; M. D. Womack and T.
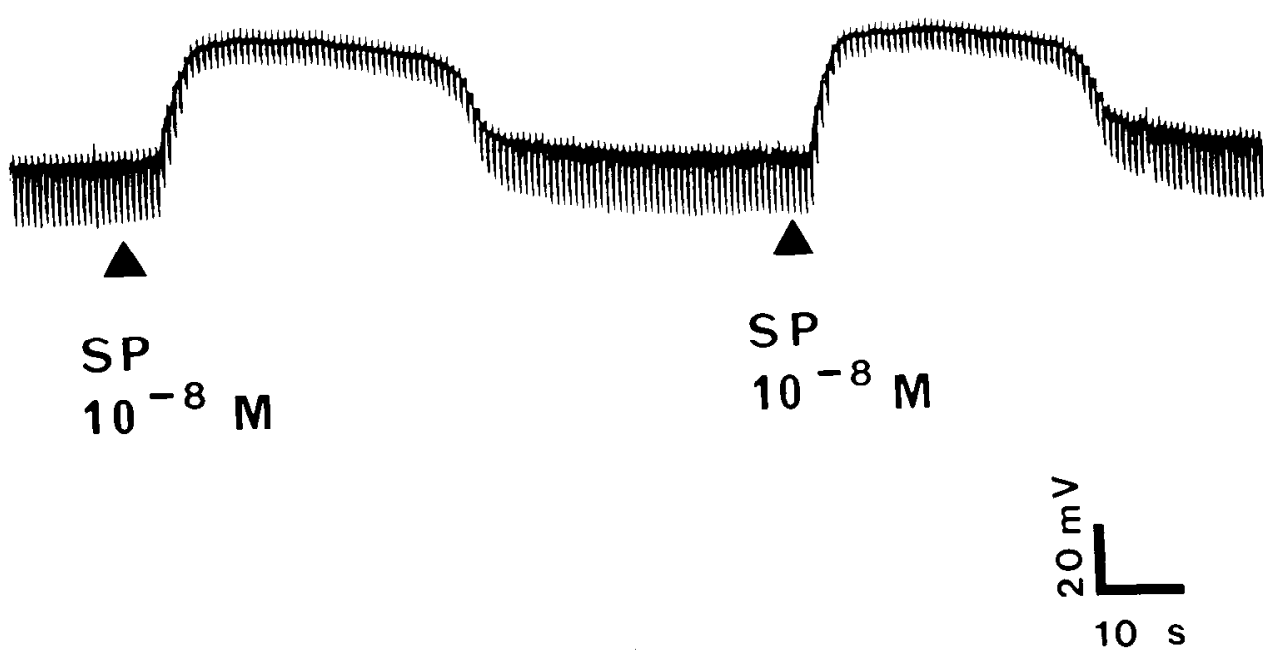

Figure 7. Depolarization of AR4-2J cells by SP. The chart record obtained from an intracellular recording from a single AR4-2J cell grown in culture for $48 \mathrm{hr}$ is shown. Resting membrane potential before application of SP was $-65 \mathrm{mV}$. Application of SP $\left(10^{-8} \mathrm{M}\right)$ evoked a large depolarization. SP was applied from a pressure electrode ( 3 to $5 \mu \mathrm{m}$ tip diameter, 1 p.s.i., $100 \mathrm{msec}$ duration). Downward deflections in the trace indicate changes in membrane potential produced by hyperpolarizing current pulses. A second application of SP elicited a similar depolarization. 
Figure 8. Amylase release from AR4-2J cells in response to SP and other secretagogues. In $A$ the amount of amylase release is expressed as the percentage of total cellular stores and is plotted as a function of increasing SP concentration. Each point is the mean \pm SEM of four determinations and is representative of two additional experiments. In $B$, amylase release induced by $\mathrm{SP}$ is plotted as a function of cell number and is compared to the release evoked by several other acinar cell secretagogues. Of the other compounds tested, only bombesin evoked a significant release of amylase from AR4-2J cells. CON, contro; SP, Sp, $1 \mu \mathrm{M}$; Carb, carbachol, $100 \mu \mathrm{M} ; P E$, phenylephrine, $100 \mu \mathrm{M}$; Bom, bombesin $10 \mu \mathrm{M}$; $B K$, bradykinin, $10 \mu \mathrm{M}$; Sec, secretin, $10 \mu \mathrm{M}$. Each value is the mean \pm SEM of four determinations.
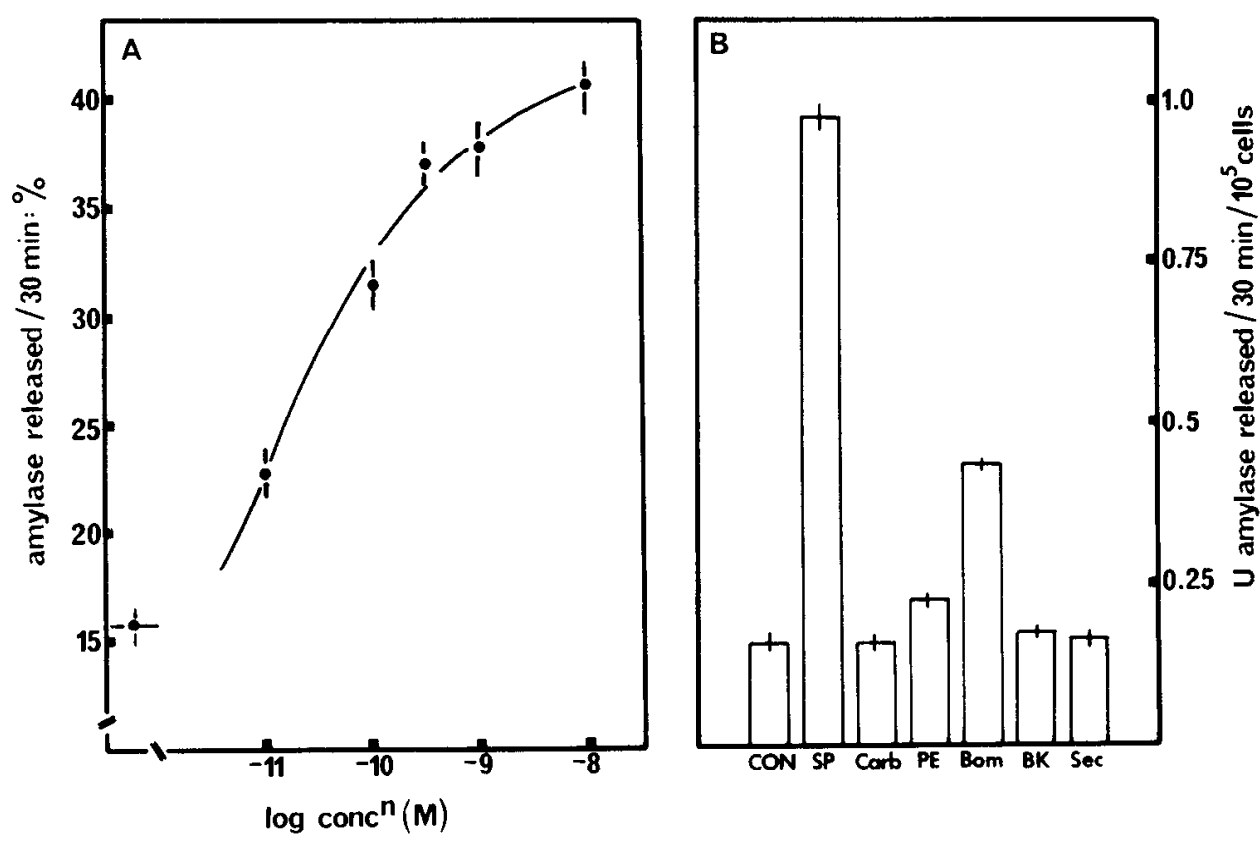

M. Jessell, unpublished observations). Other cell lines have been reported to express receptors for $\mathrm{SP}$, although the functional consequences of receptor activation on these lines is less clear. The LRM-55 glial cell line has been shown to possess SP-P-binding sites that are functional by the criterion of peptide-induced taurine release (Lepore et al., 1984). The IM9 human lymphoblast line has also been demonstrated to express binding sites which exhibit a similar ligand specificity to that of AR4-2J cells (Payan et al., 1984). SP also modulates the action of nicotinic agonists on PC12 cells (Stallcup and Patrick, 1980; Clapham and Neher, 1984), although this action appears to be mediated by low affinity binding sites with a ligand specificity that is distinct from those of the tachykinin receptors present on most mammalian neurons and acinar cells (Boyd et al., 1983). A low affinity SP-binding site has been detected on the neuroblastoma-glioma hybrid line $108 \mathrm{CC} 15$ which may mediate increases in cation permeability; however, the structural specificity of this site has not been determined (Reiser et al., 1982).

Kinetic studies on intact AR4-2J cells revealed a slow association rate and high affinity $\left(K_{D}=40 \mathrm{pM}\right)$ binding of ${ }^{125} \mathrm{I}-\mathrm{BHSP}$. Studies on ${ }^{125}$-BHSP binding to membrane preparations of acinar cells (Liang and Cascieri, 1981), to brain (Hanley et al., 1980b), or to cryostat sections of CNS tissue (Quirion et al., 1983) have revealed sites with a significantly lower affinity, in the range of $1 \mathrm{~nm}$. One possible reason for the difference in affinity may be the use of intact cells in the present study. In preliminary binding experiments performed on membrane fractions prepared from AR4-2J cells, we found an apparent $K_{\mathrm{D}}$ of $200 \mathrm{pm}$ and a significant increase in the rates of association and dissociation (Hanley et al. 1984). Beaujouan et al. (1982) have reported the equilibrium dissociation constant of ${ }^{125}$. BHSP binding to intact mesencephalic cells in culture to be $80 \mathrm{pm}$.

The binding sites on AR4-2J cells exhibited a marked preference for SP and physalaemin over kassinin and neurokinin A, suggesting that the receptor site on AR4-2J cells resembles the SP-P subclass of sites defined by Iversen et al. (1982). Binding sites for which neurokinins $A$ and $B$ may represent physiological ligands have been described in certain peripheral tissues (Buck et al., 1984) and in rat cortical membranes (Cascieri et al., 1985), but it has not yet been determined whether these sites are present on AR4-2J cells. Ligandbinding studies on membranes prepared from parotid acinar cells have documented the absence of a detectable SP-E site (Cascieri et al., 1985).

Ligand-binding studies have detected no significant differences in the pharmacological profile of tachykinin sites on AR4-2J cells and on primary acinar cells from the pancreas and parotid. However there is an apparent difference in the number of binding sites on primary and transformed acinar cells. AR4-2J cells express approximately 10,000 sites/cell, whereas the number of binding sites for ${ }^{125} \mathrm{l}$-labeled physalaemin and ${ }^{125} \mathrm{~K}-\mathrm{BHSP}$ on pancreatic acinar cells has been reported to be in the range of 200 to 1500 (Jensen and Gardner, 1979; Liang and Cascieri, 1981). AR4-2J cells therefore appear to exhibit a marked elevation in tachykinin receptor density.

By all criteria we have so far used, the tachykinin-binding sites on AR4-2 $\mathrm{J}$ cells are coupled, functionally, to membrane, intracellular, and secretory responses normally observed with parotid and pancreatic acinar cells. SP appeared to be more potent $\left(\mathrm{EC}_{50}=3 \times\right.$ $10^{-11} \mathrm{M}$ ) in stimulating amylase release than in inhibiting ${ }^{125} / \mathrm{BHSP}$ binding to AR4-2 $J$ cells $\left(C_{50}=3 \times 10^{-10} \mathrm{M}\right)$, suggesting that occupancy of a fraction of binding sites may be sufficient to trigger a maximal secretory response. Similar conclusions have been derived from studies of tachykinin receptors present on guinea pig pancreatic acinar cells (Jensen and Gardner, 1979). The threshold concentration of SP $\left(10^{-10} \mathrm{M}\right)$ required to increase $\left(\mathrm{Ca}^{2+}\right)$, was also less than the $\mathrm{IC}_{50}$ value obtained from ligand-binding studies.

It is interesting that bombesin was the only other pancreatic secretagogue that was observed to stimulate amylase release. The SP antagonist D-Arg ${ }^{1}-\mathrm{D}-\mathrm{Pro}^{2}$-D-Tryp ${ }^{7.9}$-Leu $^{11} \mathrm{SP}$ has recently been shown to antagonize release of amylase, evoked by SP and also by bombesin, gastrin-releasing peptide, and several other structurally related amphibian peptides (Jensen et al., 1984). The biding sites for SP, bombesin, and other related peptides on acinar cells may, therefore, share structural features. Further studies on AR4-2J cells may be useful in elucidating the relationship between the receptors for these peptides on acinar cells. The failure of other secretagogues to elicit release of amylase may reflect an absence of receptor sites on AR4-2J cells. Alternatively, AR4-2J cells may be deficient in membrane transduction systems that mediate responses to these secretagogues on primary acinar cells.

The membrane events that lead to the SP-induced rise in $\left(\mathrm{Ca}^{2+}\right)_{\mathrm{i}}$ in pancreatic acinar cells have not been examined in the present experiments. From studies with SP on parotid cells (Hanley et al., $1980 \mathrm{a}$ ) and with other secretagogues on rat pancreatic acinar cells (Putney et al., 1983), it seems probable that SP enhances the turnover of membrane polyphosphoinositides and leads to the intracellular release of inositol trisphosphate which has been proposed to mediate increases in $\left(\mathrm{Ca}^{2+}\right)$ ( Streb et al., 1983). Recently, SP has, in fact, been shown to lead to an increase in inositol trisphosphate 
levels in AR4-2J cells (R. J. Miller, personal communication). A correlation in the autoradiographic distribution of SP-P-binding sites and SP-induced inositol phosphate turnover had been reported in the CNS (Mantyh et al, 1984C). If, as seems likely, many of the effects of SP on AR4-2J cells are mediated by changes in membrane polyphosphoinositide turnover, studies on AR4-2J cells may also provide insights into the mechanisms of action of SP on neuronal cells. Diacylglycerol, a second product of phosphatidylinositol hydrolysis, has been shown to activate protein kinase C (Nishizuka, 1983), raising the possibility that SP may have additional effects on neurons and acinar cells.

The AR4-2J line should provide a suitable cellular system for examining the structural properties of a characterized population of tachykinin-binding sites and the responses elicited by SP-receptor activation.

\section{References}

Albert, P. R., and A. H. Tashjian (1984) Thyrotropin-releasing hormone induced spike and plateau in cytosolic free $\mathrm{Ca}^{2}$ concentration in pituitary cells. J. Biol. Chem. 259: 5827-5832

Beaujouan, J. C., Y. Torrens, A. Herbert, M. C. Daguet, J. Glowinski, and A. Prochiantz (1982) Specific binding of an immunoreactive and biologically active ${ }^{125}$. labeled substance $P$ derivative to mouse mesencephalic cells in primary culture. Mol. Pharmacol. 22: 48-55.

Bolton, A. E., and W. M. Hunter (1973) The labeling of proteins to high specific radioactivities by conjugation to a ${ }^{125} /$-containing acylating agent. Biochem. J. 133: 529-539.

Boyd, N. D., M. P. Anthony, and S. E. Leeman (1983) Structure-activity relationships of the inhibitory actions of substance $P$ on nicotinic cholinergic receptors. Soc. Neurosci. Abstr. 9: 142.

Brown, C. L., and M. R. Hanley (1981) The effects of substance P and related peptides on $\alpha$-amylase release from rat parotid gland slices. $\mathrm{Br}$. J Pharmacol. 73: 517-523.

Buck, S. H., E. W. Burcher, C. W. Schults, W. Lovenberg, and T. L. O'Donohue (1984) Novel pharmacology of substance K-binding sites: A third type of tachykinin receptor. Science 226: 987-989.

Cascieri, M. A., G. G. Chicchi, and T. Liang (1985) Demonstration of two distinct tachykinin receptors in rat brain cortex. J. Biol. Chem. 260: 15011507.

Charlton, C. G., and C. J. Helke (1984) Substance P receptors are present in autonomic and respiratory nuclei in the spinal cord. Soc. Neurosci Abstr. 10: 378

Clapham, D. E., and E. Neher (1984) Substance P reduces acetyicholine induced currents in isolated bovine chromaffin cells. J. Physiol. (Lond.) 347: $255-277$

Cuello, A. C., J. V. Priestly, and M. R. Matthews (1982) Location of substance $P$ in neuronal pathways. Ciba Found. Symp. 91: 55-79.

Fischer, E. H., and E. A. Stein (1961) $\alpha$-Amylase from human saliva. Biochem. Prep. 8: 27-29.

Fogh, J. (1975) Human Tumor Cells In Vitro, Plenum Press, New York.

Gallacher, D. V. (1983) Substance $P$ is a functional transmitter in the rat parotid gland. J Physiol (Lond) 347: 483-498

Hanley, M. R., and T. M. Jessell (1984) Substance $P$ receptors on a rat pancreatic acinar cell line. J. Physiol. (Lond.) 351:29P.

Hanley, M. R., C. M. Lee, L. M. Jones and R. H. Michell (1980a) Similar effects of substance $P$ and related peptides on salivation and on phos phatidylinositol turnover in rat salivary glands. Mol. Pharmacol. 18:78-83.

Hanley, M. R., B. E. B. Sandberg, C. M. Lee, L. L. Iversen, D. E. Brundish, and R. Wade (1980b) Specific binding of ${ }^{3} \mathrm{H}$-substance $P$ to rat brain membranes. Nature 286: $810-812$.

Hanley, M. R. I. M. Jessell, C. Jones, D. Macallan L. Probert, H. P. I oo, M. J. O. Wakelam, and G. Zamboni (1984) Peptide receptors in the brain and periphery. Clin. Neuropharmacol. 7: 48-49.

Harmar, A. J., and P. Keen (1984) Rat sensory ganglia incorporate radiolabeled amino acids into substance $\mathrm{K}$ (neurokinin $\alpha$ ) in vitro. Neurosci. Lett. 51: $387-391$

Hokfelt, T., S. Vincent, C. -J. Dalsgaard, L. Skirboll, O. Johansson, M Schultzberg. J. M. Lundberg, S. Rosell, B. Pernow, and G. Jancso (1982) Distribution of substance $P$ in brain and periphery and its possible role as a co-transmitter. Ciba Found. Symp. 91: 186-205.

Innis, R. B., R. Andrade, and G. K. Aghajanian (1984) Substance K excites substantia nigra neurons in rat. Soc. Neurosci. Abstr. 10:812.

Jensen, R. T., and J. D. Gardner (1979) Interaction of physalaemin, substance
$P$ and eledoisin with specific membrane receptors on pancreatic acinar cells. Proc. Natt. Acad. Sci. U. S. A. 76: 5679-5683.

Jensen, R. T., S. W. Jones, K. Folkers, and J. D. Gardner (1984) A synthetic peptide that is a bombesin receptor antagonist. Nature 309: 61-63.

Jessell, T. M. (1983) Substance $P$ in the nervous system. In Handbook of Psychopharmacology. Vol. 16, Neuropeptide, L. L. Iversen, S. D. Iversen and S. H. Snyder, eds., pp. 1-105, Plenum Press, New York and London. Jessop, N. W. and R. J. Hay (1980) Characteristics of two rat pancreatic exocrine cell lines derived from transplantable tumors. In Vitro 16: 212.

Kanazawa, K., T. Ogawa, S. Kimura, and E. Munekata (1984) Regional distribution of substance $\mathrm{P}$, neurokinin $\alpha$ and neurokinin $\beta$ in rat central nervous system. Neurosci. Res. 2: 111-120.

Kangawa, K., N. Minamino, A. Fukada, and H. Matsuo (1983) Neuromedin $\mathrm{K}$ : A novel mammalian tachykinin identified in porcine spinal cord. Biochem. Biophys. Res. Commun. 114: 533-540.

Kimura, S., M. Okada, Y. Sugita, M. I. Kanazawa, and E. Munekata (1983) Novel neuropeptides, neurokinin $\alpha$ and $\beta$ isolated from porcine spinal cord. Proc. Jpn. Acad. Ser. B. 59: 101-104

Kitabgi, P.. K. Carraway, J. Van Rietschoten, C. Granier, J. L. Morgat, A. Menez, S. Leeman, and P. Freychet (1977) Neurotensin: Specific binding to synaptic membranes from rat brain. Proc. Natl. Acad. Sci. U. S. A. 74: 1846-1850.

Konishi, S., A. Tsunoo, and M. Otsuka (1980) Peptidergic excitatory and inhibitory synapses in mammalian sympathetic ganglia: Roles of substance $\mathrm{P}$ and enkephalin. Biomed. Res. 1: 528-536.

Larsson, L. I. (1979) Innervation of the pancreas by substance $P$, enkephalin vasoactive intestinal polypeptide and gastrin/CCK immunoreactive nerves. J. Histochem. Cytochem. 27: 1283-1284.

Lee, C. M., L. L. Iversen, M. R. Hanley, and B. E. B. Sandberg (1982) The possible existence of multiple receptors for substance P. Naunyn-Schmeidebergs. Arch. Pharmacol. 318: 281-287.

Lepore, R. E., W. A. Shain, and M. H. Perrone (1984) Modulation of ${ }^{3} \mathrm{H}$ substance $P$ binding to LRM 55 cells by cations and nucleotides. Soc Neurosci. Abstr. 10: 213 .

Liang, T., and M. A. Cascieri (1979) Substance P stimulation of amylase release by isolated parotid cells and inhibition of substance $P$ induction of salivation by vasoactive peptides. Mol. Cell. Endocrinol. 15: 151-162.

Liang, T., and M. A. Cascieri (1981) Substance P receptor on parotid cell membranes. J. Neurosci. 1: 1133-1141.

Logsdon, C. D., J. Moessner, J. A. Williams, and I. D. Goldfine (1985) Glucocorticoids increase amylase mRNA levels, secretory organclics, and secretion in pancreatic acinar AR4-2J cells. J. Cell Biol. 100: 1200-1208.

Longnecker, D. S., H. S. Lilia, J. French, E. Kuhlmann, and W. Noll (1979) Transplantation of azaserine induced carcinomas of pancreas in rat. Cancer Lett. 7: 197-202.

Maggio, J. E., B. E. B. Sandberg, C. V. Bradley, L. L. Iversen, S. Santikarn B. H Williams, J. C. Hunter, and M. R. Hanley (1983) Substance K, a nove tachykinin in mammalian spinal cord. In Substance $P, P$. Skrabanek and D. Powell, eds., p. 20, Poole Press, Dublin.

Mantyh, P., S. P. Hunt, and J. E. Maggio (1984a) Substance P receptors Localization by light microscopic autoradiography in rat brain using ${ }^{3} \mathrm{H}$ substance $P$ as the radioligand. Brain Res. 307: 147-165.

Mantyh, P. W. J. E. Maggio, and S. P. Hunt (1984b) The autoradiographic distribution of kassinin and substance $K$ binding sites is different from the distribution of substance $P$ binding sites in rat brain. Eur. J. Pharmacol. 102: $361-364$

Mantyh, P. W. R. D. Pinnock, C. P. Downes, M. Goedert, and S. P. Hunt (1984c) Corrclation between inositol phospolipid hydrolysis and substance $P$ receptors in rat CNS. Nature 309: 795-797.

Minamino, N., H. Masuda, K. Kanazawa, and H. Matsuo (1984) Regional distritution of neuromedin $K$ and neuromedin $L$ in rat brain and spina cord. Biochem. Biophys. Res. Commun. 124: 731-738.

Nishiyama, A., and O. H. Petersen (1974) Pancreatic acinar cells: Membrane potential and resistance changes evoked by acetylcholine. J. Physiol. (Lond.) 238: 145-158.

Nishiyama, A., and O. H. Petersen (1975) Pancreatic acinar cells: Ionic dependence of acetylcholine-induced membrane potential and resistance changes. J. Physiol. (Lond.) 244: 431-465.

Nishizuka, Y. (1983) Calcium, phospholipid turnover and transmembrane signaling. Philos. Trans. R. Soc. Lond. (Biol.) 302: 729 734.

Ochs, D. L., J. I. Korenbrot, and J. A. Williams (1983) Intracellular free calcium concentrations in isolated pancreatic acini; effects of secretagogues. Biochem. Biophys. Res. Commun. 117: 122-128

O'Doherty, J., and R. J. Stark (1982) Stimulation of pancreatic acinar secretion. Increases in cylusulic calcium and sodium. Am. J. Physiol. 242: G513-G521 
Payan, D. G., D. R. Brewster, and E. J. Goetzl (1984) Sterospecific receptors for substance $P$ on cultured human IM-9 lymphoblasts. J. Immunol. 133: 3260-3265.

Petersen, O. H. (1980) The electrophysiology of gland cells. Academic Press, $253 \mathrm{pp}$.

Petersen, O. H., and Y. Maruyama (1984) Calcium activated potassium channels and their role in secretion. Nature 307: 693-696.

Porter, R., and M. O'Connor (1982) Substance $P$ in the Nervous system. Ciba Found. Symp. 91: 1-349.

Putney, J. W., C. M. Van De Walle, and B. A. Leslie (1978) Receptor contro of calcium influx in parotid acinar cells. Mol. Pharmacol. 14: 1046-1054.

Putney, J. W., G. W. Burgess, S. P. Halenda, J. S. McKinney, and R. P Rubin (1983) Effects of secretagogues on ( $\left.{ }^{32} \mathrm{P}\right)$ phosphatidylinositol 4,5bisphosphate metabolism in the exocrine pancreas. Biochem. J. 212 $483-488$

Quirion, R., C. W. Shults, T. W. Moody, C. B. Pert, T. N. Chase, and T. L. O'Donohue (1983) Autoradiographic distribution of substance $\mathbf{P}$ receptors in rat central nervous system. Nature 303: 714-716.

Rao, K. N., S. Takahashi, H. Shinozuka (1980) Acinar cell carcinoma of the rat pancreas grown in cell culture and in nude mice. Cancer Res. 40: 592597.

Reiser, G., K. Folkers, and B. Hamprecht (1982) Substance P enhances cation permeability of neuronal cell lines. Regul. Pept. 5: 85-93.

Rosell, S., U. Bjorkroth, J. C. Xu, and K. Folkers (1983) The pharmacological profile of a substance $P$ antagonist. Evidence for the existence of subpopulations of substance P receptors. Acta Physiol. Scand. 117: 445-449.

Sharkey, K. A., and R. G. Williams (1983) Extrinsic innervation of the rat pancreas: Demostration of vagal sensory neurons in the rat by retrograde tracing. Neurosci. Lett. 42: 131-135.

Sjodin, L., T. P. Conlon, C. Gustavson, and K. Uddholm (1980) Interaction of substance $P$ with dispersed pancreatic acinar cells from the guinea pig. Stimulation of calcium outflux, accumulation of cyclic GMP and amylase release. Acta Physiol. Scand. 109: 107-110

Stallcup, W. B., and J. Patrick (1980) Substance P enhances cholinergic receptor sensitization in a clonal nerve cell line. Proc. Natl. Acad. Sci. U S. A. $77: 634-638$.

Streb, H., R. F. Irvine, M. J. Berridge, and I. Schulz (1983) Release of Ca ${ }^{2+}$ from a non-mitochondrial intracellular store in pancreatic acinar cells by inositol-1,4,5-triphosphate. Nature 306: 67-69

Tsien, R. Y., T. Pozzan, and T. J. Rink (1982) Calcium homeostasis in intact lymphocytes: Cytoplasmic free calcium monitored with new, intracellularly trapped fluorescent indicator. J. Cell Biol. 94: 325-344.

Urban, L., and M. Randic (1984) Slow excitatory synaptic transmission in rat dorsal horn: Possible mediation by peptides. Brain Res. 290: 336-341.

Walker, M. D., T. Edlund, A. M. Boulet, and W. J. Rutter (1983) Cell-specific expression controlled by the $5^{\prime}$-flanking region of insulin and chymotrypsin genes. Nature 306: 557-561.

Womack, M. D. M. R. Hanley, and T. M. Jessell (1984) Substance P receptor mediated responses in a rat pancreatic acinar cell line. Soc Neurosci. Abstr. 10: 213

Yaksh, T. L., T. M. Jessell, R. Gamse, A. W. Mudge and S. E. Leeman (1980) Intrathecal morphine inhibits substance $P$ release from mammalian spinal cord in vivo. Nature 286: 155-157. 